\title{
INCREASING THE THE ABILITY WRITING SHORT STORIES THROUGH METACOGNITIVE STRATEGIES
}

\author{
Dessy Wardiah \\ FKIP-Universitas PGRI Palembang, Indonesia \\ dessywardiah77@gmail.com
}

\begin{abstract}
The objective of this research is to find the increasing of the process and the result student's short story writing through metacognitive strategy in language and Indonesia Literature Study Programme FKIP-PGRI University of Palembang. This research uses action research method which is done through planning, action, observation, and reflection. This research was conducted through three cycles, from the result of learning process is found that students have been able to make a planning, monitoring, evaluation and revising according to metacognitive strategy cycle, during their time in writing short story task. This research find out that there had been an increased from the short story writing result in every of its cycle. On the first cycle, there are 8 (eight) students who accomplished the task, with average score is in 64,16. On the second cycle, it showed a significant increased, there were 29 (twenty nine) students who accomplished and 9 (nine) students have not accomplished the task, with average score is ini 72, 18. And the third cycle, there were 38 (thirty eight) students who accomplished the task in the short story writing learning process with average score was in 77,05.
\end{abstract}

Keywords: Writing Ability; Short Story; Metocignitive Strategy.

In college, the ability to write an effective training practices in the Indonesian language in writing. Writing activities are an integral part in all the activities of the students' learning during studying high diperguruan. Students are trained to be able to express ideas or his ideas, both scientific and imaginative and expressive through writing. For that a writer must know what to write, what is the purpose of writing, for whom the results of write and how to write

It Is not an exaggeration to say that writing ability is the ability of a complex, demanding certain amount of knowledge and skills. To write an essay sederhanapun, technically we are required to meet the basic requirements such as when we write complex bouquet. We must choose a topic, limit, develop ideas, presenting them in sentences and paragraphs are arranged logically and so forth. (Akhadiah, 2002: 2)

Familiarize the student is able to write short stories in this writing is certainly not easy to implement. Develop an idea, opinion, and experience into a speaking circuit board regular, systematic and logical is not an easy job, but a job that requires continual practice. Various obstacles can be felt when it has been in the classroom and deal with diverse student character. Therefore, the development of an appropriate strategy is needed to make the learning process more fun so that the learning objectives can be achieved

From the results of pre-tests and observation, researchers menenggarai cause of the low ability students to write short stories is due; (1) teachers do not find the right strategy to improve the writing skills of students especially in writing short stories, (2) learning to write committed teachers during this too product-oriented (outcome) and ignores the process, (3) the relationship of teacher and student in a process 

activity teaching and learning are relatively formal and rigid, so the creative thinking of students are less well honed. (4) which is emphasized in the learning process, especially the theory of the criteria stated in advance and then writing a new practice of writing; (5) exercise less attention to write short stories in detail

Prasiklus results also reflected their inability factor of students in expressing and developing ideas or ideas in writing, students are also less capable of organizing the writing, and the lack of mastery of language skills such as the choice of words (diction), language, punctuation and written conventions. Besides thinking during this imprinted in mind the students is that writing is hard to make students feel skeptical and less confident to write.

In connection with the implementation and effectiveness metacognitive strategies to increase skills deemed necessary to write short stories performed on students of Language and Literature Education Indonesia University PGRI Palembang. How is the process of improving student learning to write short stories performed by using metacognitive strategies ?, How is the resulting increase students' ability to write short stories metacognitive by using a strategy metacognitive.

\section{Writing ability}

Stenrberg (in Wardarita, 2010: 13), "The ability meant to indicate a specific action or special duty, both physically and mentally. Ability is the result of learning obtained learners after attending a lesson ". Every human being of course provided the ability in different capacities. The term capability, berdenotasi with competence that is characteristic displayed by someone on ways to behave or think about some things and persist for a long time.

Capability also means the same as the skill and power to do something. Ability is the power to act as a result of the nature and practice (Semiawan, 1987: 2). Means the ability of a force to be obtained from birth should also be geared up with exercises optimal working to improve the personal qualities of an individual. One of the capabilities possessed by human beings is to communicate with spoken language and written language. For oral activity is called talking to and writing activities is called writing. Writing is a skill that is very complex.

Writing is a creative process steps. This means that writing is a skill which is done through the stages that must be done by mobilizing skills, arts and tips so that everything runs effectively (Spring, 2007: 10). The Writing is a private activity may be broadly seen as Comprising four main stage: planning, drafting, revising, editing (Krasen in Richard, 2002: 315). meaning that writing is an individual activity that can be seen as a merger of four things, namely planning, drafting, revising, and editing. An article can be fun to read if laid out in such a way, so it will be a series of words or phrases that are both cohesive and coherent. (Wardarita, 2010: 14)

In writing activities, of course, there are goals to be accomplished writer. Interest write the main thing is to convey a message from the writer to the reader itself, so that the reader understands the intent to convey the author through his writings. Theoretically knowledge of technical writing itself is not a guarantee we can be a good writer because writing is not instant activity. The best way to learn how to write well is to practice writing.

\section{Short Story}

The short story is a story in prose that is relatively short, said to be short too because this genre has only one single effect, characters, plot and setting are limited, 
not varied and complex (Saini, 1990: 30). Tarin call it concentrated on one event (Tarin, 1986: 38). The short story is a prose short story. Determination of short size, is relative. Edgar Alan Poe, the famous American writer outlines short size is finished read in one sitting, roughly ranging from half to two hours. As with the Nurgiyantoro (2010: 10), who saw the size of the short terms of quantity, ie the number of words spoken: there is a short story shorter, perhaps very short, ranging from 500 s of words (short-short story), there is a short story length is mediocre (midle short story).

Based on the above it can be concluded, the short story is the story of a fictional narrative, which is short and the overall story gives the impression of a single. A short story will certainly stand and built by builder elements of stories both intrinsic and extrinsic elements. Nurgiyantoro (2010: 10) describes in outline the elements of the builder of a work of Satra, including short stories grouped into two parts, namely the elements intrinsic (elements that build literary work itself) and extrinsic elements (elements outside work Satra it. that included an element intrinsic include events, story, plot, characterization, theme, background, viewpoint storytelling, language or style. While extrinsic elements include a biography of the author or events subjectivity of individual authors who have attitudes, beliefs, and outlook on life all of which will affect the work he has written. in addition, a story must also have achieved a kind of structure, the structure is referred to in a series of short stories is a story in which there is an arrangement of stories beginning or introduction, middle or core, and the final section or cover

\section{Metacognitive Strategy}

John Flavell originator of the term metacognitive, simply define metacognitively as "knowing about knowing" knowledge about knowledge. Metacognition refers to a person's knowledge of their own cognitive processes or anything related to them, such as learning relevant nature of the information or data (Serra, 2009: 278). Hope J. Hartman (2002: xi) states that It is Generally defined as cognition about cognition or thinking about one's own thinking, Including both the processes and the product. That metakonitif are generally defined as cognition about cognition or thinking about ourselves, including both the process and product.

Metacognitive strategies to bring learners to a process they call the mental modeling (model thinking). In teaching the thinking process, learners need to do the following. (1) focusing learners), (2) emphasis on the values of the demonstration, (3) talking in the language of conversation, (4) to make the steps simple and clear, (5) helps students remember (Yamin, 2013: 29 -30).

Metacognitive relates to a process of thinking students about thinking, thinking can mean that a person know (metacognition knowledge), what someone is doing (metacognitive skills), or experience kognitive what someone is doing at this time (experience metacognition). And one of the aspects used in metacognitive strategies is the executive controls, including planning, evaluation, monitoring, and revision (Brown in Mckeown, 2009: 7). For the implementation of the main metacognitive learning must be owned by a learner is awareness. consciousness referred to in metacognitive strategies is the ability to do self reflection, self-monitoring, or self awareness of learning activities that have been carried out (Yamin, 2013: 31).

In this study, researchers used a model Excutive Control Brown, "These models features a central processors that can control its own operations, the which include planning, monitoring, evaluation, revising" Brown in Douglash (1998: 7). The model 
proposed by Brown consists of four metacognitive processes, including planning, monitoring, evaluation, revision.

\section{METHOD}

The research was conducted on a semester students II.A Academy Year 2014/2015, Prodi Indonesian Language and Literature, University FKIP PGRI Palembang, as many as 38 people. Research was conducted during one semester from February to May 2015. This study aims to improve students' ability to write a short story on a subject to write-up in the Education Studies Program Indonesian Language and Literature University of PGRI Palembang using Action Research Methods (Action Research).

This action research model refers to a model Kemmis and Taggart, which is conducted through three (3) cycles. Each cycle shall be composed of four stages: (1) planning the action, (2) action, (3) observation of action, and (4) reflection does in a spiral system (Koshy, 2005: 4)

Criteria for the success of research seen from a comparison value before administration and after administration action action. Improved learning outcomes expressed succeed if the value obtained by the students achieve an average value above 70 , with $75 \%$ mastery learning classical. For the collection of data regarding the ability to write short stories, created a research instrument that was developed from the definition of a conceptual and operational definitions as follows

Table 1. Capability Assessment Rubric Students in Writing Short Stories

\begin{tabular}{|c|c|c|c|c|}
\hline No & $\begin{array}{c}\text { Aspects } \\
\text { Rating }\end{array}$ & Details Ratings & $\begin{array}{l}\text { Score } \\
\text { range }\end{array}$ & Categories \\
\hline \multirow[t]{3}{*}{1} & Theme & $\begin{array}{l}\text { Good and clear in describing the themes } \\
\text { contained in the story, both in presenting } \\
\text { the theme of the conclusion of the whole } \\
\text { story and themes raised issues of life }\end{array}$ & $8,1-10$ & Hight \\
\hline & & $\begin{array}{l}\text { Quite good and clear in describing the } \\
\text { themes contained in the story, is quite } \\
\text { good in presenting the theme of the } \\
\text { conclusion of the whole story and themes } \\
\text { raised issues of life. }\end{array}$ & $4,1-10$ & Midle \\
\hline & & $\begin{array}{l}\text { Less good and less clear in describing the } \\
\text { themes contained in the story, is not good } \\
\text { in presenting the theme of the conclusion } \\
\text { of the whole story and themes raised issues } \\
\text { of life. }\end{array}$ & $2-4$ & Low \\
\hline \multirow[t]{3}{*}{2} & $\begin{array}{l}\text { Characters and } \\
\text { Characterizatio } \\
\text { ns }\end{array}$ & $\begin{array}{l}\text { The characterization of figures depicted in } \\
\text { sharp detail and real, a character capable } \\
\text { of bringing the reader experience the } \\
\text { events of the story }\end{array}$ & $8,1-10$ & Hight \\
\hline & & $\begin{array}{l}\text { The characterization of figures depicted } \\
\text { quite sharp and detailed and quite real, } \\
\text { quite figure able to bring the reader } \\
\text { experience the events of the story }\end{array}$ & $4,1-8,0$ & Midle \\
\hline & & $\begin{array}{l}\text { The characterization of figures depicted } \\
\text { are not sharp, no details and no real, } \\
\text { leaders can not afford to bring the reader } \\
\text { experience the events of the story. }\end{array}$ & $2-4$ & Low \\
\hline
\end{tabular}


3 plots

4 Setting/

Background

$5 \quad$ Storytelling style

Dictions

7

Spelling

Sentences

paragraph
Groove game interesting and clear.

Groove game interesting enough and clear enough.

Games groove unattractive and obvious.

Precise and detailed in choosing a place

that confirm the occurrence of events, just

select the appropriate time with the events

in the story, precise and detailed describe atmosphere that supports events.

Right enough and detailed enough in choosing which confirmed the occurrence of events, quite appropriately choose the appropriate time with the events in the story, quite precise and detailed enough to describe the atmosphere that supports events

Less precise and less detailed in choosing a place that confirm the occurrence of the event, is not right to choose the time that corresponds to the events in the story, is less precise and detailed describes the atmosphere to support event.

Right to choose the language that contains elements of emotive and connotative nature, right in choosing the phrase that represents something so as to give rise to associations / interesting images.

Appropriately enough in choosing which contains elements of emotive language and is connotative, appropriately enough in choosing the phrase that represents something that is quite capable of causing association / images that attract

Less precise in choosing a language containing elements of emotive and connotative nature, less precise in choosing the phrase that represents something that is less capable of causing association / images that attract

Choice of words appropriate to the theme of the story.

Choice of words is quite precise and quite in keeping with the theme of the story.

Choice of words inappropriately and not in accordance with the theme of the story.

All spelling and punctuation correctly.

Only a few spelling and punctuation is wrong.

Many spelling and punctuation is wrong.

The phrase used is effective sentence, and easy to understand.

Sentences that are used quite effectively, and it is quite understandable

Sentences that are used are not effective, and difficult to understand

There is unity in the paragraph which is characterized by the subject matter, other $\begin{array}{cr}8,1-10 & \text { Hight } \\ 4,1-8,0 & \text { Midle } \\ 2-4 & \text { Low } \\ 8,1-10 & \text { Hight }\end{array}$

4,1-8,0 Midle

$2-4 \quad$ Low

8,1 - $10 \quad$ Hight

4,1-8,0 Midle

2-4 Low

4,1 - 5,0 Hight

2,1 - 1,0 Midle

1 - 2 Low

4,1-5,0 Hight

2,1 $-1,0 \quad$ Midle

1 - 2 Low

4,1-5,0 Hight

2,1 - 1,0 Midle

$1-2 \quad$ Low

4,1-5,0 Hight 
9 Viewpoint

10 extrinsic story

11 the initial structure of the story

12 Central structure / core

13 End structure than that there is also a cohesiveness in the paragraph,

There is unity in the paragraph which is characterized by the subject matter, but no cohesion in the paragraph,

There is no unity and cohesiveness

cohesiveness in paragraphs

The author situates him clearly.

The author in putting himself sometimes in the first person, but sometimes also in the third person.

The position of writer in the story is not clear.

Being able to clearly illustrate the values (moral) contained in the short story, either implicitly or explicitly.

Quite capable of plotting the values (moral) contained in both the short story, although sometimes less obvious (implicit).

No values (moral) who is able to be described by the author.

$2,1-1,0 \quad$ Midle

$1-2 \quad$ Low

4,1-5,0 Hight

2,1-1,0 Midle

$1-2 \quad$ Low

4,1-5,0 Hight

$2,1-1,0 \quad$ Midle

$1-2 \quad$ Low

4,1 - 5,0 Hight

descriptions of characters and an interesting setting, imagery began to appear to be a conflict.

beginning of the story is marked with descriptions of characters and setting are quite interesting, but not yet appear to be a conflict imagery

The beginning of the story is not interesting.

Conflict in the story began to mount and tense, marked by characters or character actors with some hassle story began to emerge. interested readers and reluctant to stop reading because the conflict can not be predictable

Conflict in the story started to rise, but not too intense, because the character or character actors with some kerumitan kurang story appeared. readers interested enough

Conflict in the story did not appear.

2 - $4 \quad$ Low

Conflicts began to get a solution, the story ends with the authors reveal the solution experienced leaders, and end an interesting story and leave an impression for the reader so that the reader can obtain learning after reading the text of stories that are optional.

There is no process for reducing conflict yet experienced figures pengarang mengungkapkan solutions quickly, end of the story is quite interesting for the reader, the reader can obtain learning enough after reading the short story text.

No decrease in conflicts and solutions

Low

$4,1-5,0$

Hight

$2,1-1,0 \quad$ Midle experienced leaders. end of story
2,1 $-1,0 \quad$ Midle

$1-2$ Low

8,1 - $10 \quad$ Hight

4,1-8,0 Midle 


\section{RESULT AND DISCUSSION}

\section{Process Upgrades Short Story Writing Through Metacognitive Strategy}

Effective learning can certainly improve student results, the better the quality of learning, the better the student learning outcomes are achieved. The learning process in this study carried out in three cycles, each cycle consisting of four meetings. As a result of the improvement process of learning to write short stories through metacognitive strategies derived from the observation in the form of field notes the researcher, the observation of the observer (collaborators) and the student questionnaires. Activity observations (observation) coincides with the learning activities. The results of the process are outlined below.

In the planning stage, students are expected to formulate an understanding of the task, mengatifkan prior knowledge (competence Based Language) about the topic and have a plan on completion of the task. In the first cycle of students still have difficulty writing short stories, In general, students have no prior knowledge related to writing short stories, but not in detail, so with minimal knowledge of the students are not able to mengerajakan job well done. Students are not able to manage the planning of self (self-planning), or a set of learning objectives to be achieved, the time will be used to complete the task of learning, knowledge relevant thresholds, and cognitive strategies to be used in the task. In the second cycle, the students have started to focus on a given task for lecturers always control how students mencanakan, set goals, organize and schedule the task completion process. Most of them already understand the importance of planning the self (self-planning) in the writing process. They began to realize the importance of predicting the time needed to complete the assigned task. In the third cycle, the students looked ready with planning tasks. This is reinforced by the results of questionnaires and interviews found that students had to focus on a given task. they already understand the importance of planning the self (self-planning) in the writing process. They've realized the importance of having prior knowledge of relevant, the importance of selecting the cognitive strategies that will be used in the task, and realize the importance of taking into account the time needed to complete the assigned task.

At the monitoring stage, the student must check the information received and match the knowledge of the rules of the theory. The rules of the theory used for the development of short story writing. In the first cycle, visible process of selfmonitoring (self-monitoring), in which students are also not maximized. The process of self-monitoring includes monitoring the achievement of the objectives of learning, monitoring the time spent, monitoring the relevance of the material prior knowledge with new subject matter, and monitoring of cognitive strategies that are being used. In the second cycle, the students have started doing the monitoring phase marked by the emergence of new capabilities that check information is received and match with their knowledge and experience about the rules of the previous theory. This is evident from student discussion regarding the development of a framework sample / draft writing short stories. In the third cycle, It is clear that the students have been able to check the new information received and match with their knowledge and 
experience about the rules of the previous theory. Students have been able to consider a variety of things that are important in achieving the best decision of how to write a good short story. It is very necessary for linking information prior knowledge and experience will make development easier writing frame.

Based on evaluation result, revision and analysis of questionnaire responses provided to students also found that; application of metacognitive strategies has been to spur students to a lot of reading and studying the theory of writing short stories, metacognitive strategies also train students for independent learning, creative and innovative, but it also can make students comfortable learning, students do not feel burdened because it has been trained to develop a plan for completion task, they find their ability to write short stories increased by implementing the stages in metacognitive strategies. Some of the difficulties they can also cope well, and by applying metacognitive strategies they can monitor the progress in the ability to write short stories. They argue that metacognitive strategies can be applied in other learning and this strategy can be used lecturer in lectures.

It can be concluded the students own awareness of individuals in planning, control and evaluate their own thinking process. Or in other words the students have been able to do poses cognitive form of knowledge, experience, goals and actions to the process kognititf, by way of planning the self (self-planning), self-monitoring (self-monitoring) and self-evaluation (self-evaluation), through planning, monitoring, evaluation and revision.

\section{Results Improved Student Short Story Writing}

The results of students' ability to write short stories through metacognitive strategies in the first cycle has not been declared a success, it is seen from the results of the short story writing skills through metacognitive strategies of student learning is the final activity; (1) there are no students who receive excellent qualifications, (2) students who got good qualifications amounting to 8 people $(21.05 \%)$, (3) students who receive qualifying quite as many as 27 people $(71.05 \%)$, (4) students who receive no less qualified, and (5) highly qualified students who receive less as many as 3 people $(7.90 \%)$. From the test results also found that of the 38 students who otherwise completed as many as 8 people $(21.05 \%)$ and students who otherwise have not completed as many as 30 people $(78.95 \%)$

In the second cycle, there is an increase that is; (1) there are no students who receive excellent qualifications, (2) students who got good qualifications totaled 29 people $(76.32 \%)$, (3) students who receive qualifying quite as much as 8 people $(21.05 \%)$, (4) students who got no qualifications less by 1 person (2.63\%) (5) highly qualified students who receive no less. From the test results also found that students who otherwise completed as many as 19 people (76.32\%), and students who otherwise have not completed many as 9 people $(23.68 \%)$.

In the third cycle, the results obtained; (1) students who receive excellent qualifications numbered $3(7.89 \%)$ (2) students who got good qualifications amounted to 35 (92.11), (3) students who receive no sufficient qualifications, (4) students which received no less qualified, and (5) students who receive very less no qualifications. From the test results found that 38 students declared complete because it has got a value greater than or equal to 70 , and students who otherwise unfinished no longer exists. Thus, in terms of results, the third cycle is considered successful because all reach the set targets. 
Based on the data of the process and the resulting increase in writing short stories through metacognitive strategies of the first cycle, second cycle and third cycle it can be concluded that the application of metacognitive strategies can improve the ability to write short stories Student Language Study Program and Indonesian literature, FKIP University PGRI Palembang.

\section{CONCLUSION}

Based on the test results written in three cycles was found that (1) students who receive excellent qualifications totaling 3 or $7.89 \%$ of the 38 students (2) students who got good qualifications amounted to 35 people or 92.11 of 38 students, (3) students who receive no sufficient qualifications, (4) students who receive no less qualified, and (5) students who receive very less no qualifications. In addition, 38 students declared complete because it has got a value greater than or equal to 70, and students who otherwise unfinished no longer Based on the data of the process and the resulting increase in writing short stories through metacognitive strategies of the first cycle, sikulus II, and III cycle can be concluded that the application of metacognitive strategies can increase as the ability to write short stories

\section{REFERENCES}

Akhadiah, Sabarti , Maidar G. Arsjad, Sakura Ridwan. Pembinaan Kemampuan Menulis Bahasa Indonesia. Jakarta: Erlangga, 1991.

Mckeown, Margaret G. and Isabel L. Beck "The Role of Metacognitian and Supporting Reading Comperhension" HandBook Of Metacognition In Education. New York: Routledge. 2009.

Koshy, Valsa. Action Research for Improving Practice: A Practical Guide. London: Paul Chapman Publishing. 2005.

Yamin, Martinis. Strategi dan Metode dalam Model pembelajaran. Jakarta: Referensi (GP Press). 2013.h. 29-30.

Wardarita, Ratu. Kemampuan Menulis Karya Ilmiah 'Pendekatan Pembelajaran Kontekstual dan Penalaran Verbal”. Yogyakarta: Paraton, 2010.

Hartman.Hope J, Metacognition in Learning and Instruction. New York: SpringerScience+Bubiness Media, B.V, 2002.

Richard, Jack and Willy A. Renandya. USA: Cambrigde University Press, 2002.

Serra, Micheal J. and Janet Metcalfe, Effective Implementasion of Metacognition dalam Handbook of Metacognition in Education. New York: Rotledge. 2009. 
Semi, Atar. Dasar-Dasar Keterampilan Menulis. Bandung: Angkasa, 2007

Sumardjo, Jacob dan Saini K.M., Apresasi Kesusastraan. Jakarta: PT Gramedia. 1991.

Henry Guntur Tarigan, Prinsip-Prinsip Dasar Sastra. Bandung Angkasa: Angkasa, 1986. 